\title{
Implementasi Program Keluarga Harapan dalam Pengentasan Kemiskinan di Pesisir Selatan
}

\author{
Resy Oktaviani, Fatmariza \\ Program Studi Pendidikan Pancasila dan Kewarganegaraan \\ Universitas Negeri Padang \\ E-mail: oktavianiresy14@gmail.com
}

\section{ABSTRAK}

Program Keluarga Harapan merupakan Program upaya penanggulangan kemiskinan diberbagai daerah di Indonesia yang dikeluarkan oleh pemerintah yakni Peraturan Menteri Sosial RI No 1 Tahun 2018 yang memberi bantuan pada penduduk miskin yang rentan dalam komponen Kesehatan (ibu hamil dan balita umur 0-6 Tahun), pendidikan (SD,SMP, SMA umur 06-21 Tahun yang belum mendapatkan Pendidikan), Kesejahteraan Sosial (Lanjut usia umur 60 Tahun dan penyandang Disabilitas). Program Keluarga Harapan di Kecamatan Basa Ampek Balai, masih belum maksimal sebagaimana yang diharapkan seperti belum tepat sasaran menjangkau masyarakat miskin, masih ada penduduk yang sudah sejahtera mendapatkan bantuan, akses bantuan yang memberikan KIS, KIP dan Rastra yang belum dibagikan merata pada Keluarga Penerima Manfaat. Tujuan penelitian ini untuk mendeskripsikan Imlementasi Program Keluarga Harapan dalam Peraturan Menteri Sosial RI No 1 Tahun 2018 sekaligus mengidentifikasi penilaian Masyarakat baik yang menerima maupun yang tidak mendapatkan bantuan sosial Program Keluarga Harapan. Metodelogi yang digunakan Kualitatif Studi Kasus, Berdasarkan analisis data Hasil penelitian menunjukkan Implementasi Program Keluarga Harapan pada realitasnya dilapangan mengalami berbagai permasalahan baik kebijakan dari pusat ke Daerah dan Nagari yang bersifat Top-Down, Dampak Implementasi belum dirasakan secara optimal oleh masyarakat dari segi akses KIS dan KIP dan hambatan Implementasi Program yang dirasakan oleh Pemerintah Nagari, Pendamping dan Dinas Sosial. Selanjutnya dari penilaian masyarakat yang menerima bantuan dan yang tidak menerima bantuan bahwa peraturan tersebut belum sesuai sasaran yang telah diterapkan hal ini dibuktikan masih banyak masyarakat penerima bantuan belum mendapatkan Haknya, rendahnya masyarakat mendukung kesejahteraan sosial dalam pendidikan dan kesehatan.

Kata Kunci: implementasi, program Keluarga Harapan, kemiskinan.

\section{ABSTRACT}

The family hope is a program of poverty alleviation in some regions in indonesia issued by the government and the minister for social ri no 1 years 2018 that provided assistance to poor people are vulnerable in health component (pregnant women and infants 0-6), age years (, primary school education, junior high school a high school 06-21 in have not get an education ), social welfare (elderly 60 age years and people with disability ). The family hope 
in district Base Ampek Balai, hall still not maximum as hoped such as not reaching the poor, right on target there are still those who already get help, prosperous which gives access help KIS, KIP and rastra who have not distributed evenly on the family beneficiaries. The purpose of this research to describe imlementasi the family hope in the social affairs minister of indonesia no 1 years 2018 at once to identify the people judgment both received or Who does not have the social assistance the family of hope program. Metodelogi that is used qualitative a case study. Based on the analysis of the data the research results show the implementation of the family of hope program on the facts beg slipped to only their second field various problems that had occurred essentially and perfectly morally good and policies from the central to regional governments and nagari having the character of top-down, the impact of the implementation of has not been felt in an optimum manner by the community from the perspective of access KIS and KIP and the obstacles faced the implementation of the program that was felt by the nagari administration had, act as the of the social affairs agency .Furthermore in the people judgment that receive assistance and that did not receive the assistance that this requirement would have not been in accordance of the focal points of which it has been applied this is proven there are still many communities the recipients of assistance has not yet been receive their rights, the low level of people with social welfare of communities supported in education and health .

Keywords : implementation, Family of Hope Program, poverty

This work is licensed under the Creative Commons Attribution-ShareAlike 4.0 International License. @2019 by author and Universitas Negeri Padang.

\section{PENDAHULUAN}

Program Kelurga Harapan berdasarkan Peraturan Mentri Sosial RI Nomor 1 Tahun 2018 memberikan bantuan sosial berupa uang, barang, dan jasa kepada keluarga atau masyarakat miskin yang rentan terhadap risiko sosial. Dengan Sasaran Keluarga miskin yang rentan serta terdaftar dalam Basis Data Terpadu program penanganan fakir miskin, memiliki komponen kesehatan, keluarga yang memiliki ibu hamil/menyusui; dan anak berusia 0 (nol) sampai dengan 6 (enam) tahun. Pendidikan anak sekolah dasar/madrasah ibtidaiyah atau sederajat, anak sekolah menengah pertama/madrasah tsanawiyah atau sederajat, anak sekolah menengah atas/madrasah aliyah atau sederajat, dan anak usia 6 (enam) sampai dengan 21 (dua puluh satu) tahun yang belum menyelesaikan wajib belajar 12 (dua belas) tahundan/atau kesejahteran sosial.

Program Keluarga Harapan di Kecamatan Basa Ampek Balai masih belum maksimal seperti yang diharapkan meskipun sudah ada Peraturan Menteri No 1 Tahun 2018 Tentang Program Keluarga Harapan, hal ini diperkuat dengan pernyataan pihak PKH dari Pendamping PKH dan Kasi Bantuan dan jaminan Sosial Dinas Sosial Pemberdayaan Perempuan dan Perlindungan Anak Kabupaten Pesisir Selatan bahwa dalam penetapan sasaran PKH berdasarkan Basis Data Terpadu Penanggulangan Kemiskinan Tahun 2015, Koordinator PKH dikabupaten tidak dapat menghapus 
dan menambah peserta PKH. Meskipun masyarakat tergolong penduduk miskin dan memenuhi kriteria pada Permensos RI No 1 Tahun 2018 dalam bidang kesehatan, pendidikan dan kesejahteraan sosial namun tidak terdaftar dalam Basis Data Terpadu penanggulangan kemiskinan sehingga bantuan tersebut tidak dapat diberikan kepada masyarakat. Untuk lebih jelasnya dapat dilihat sebagai berikut:

Tabel 1 Penerima Dana PKH Pada 10 Nagari Kec. Basa Ampek Balai

\begin{tabular}{|c|c|c|}
\hline No & Nama Nagari & $\begin{array}{c}\text { Jumlah } \\
\text { Penerima } \\
\text { PKH } \\
\end{array}$ \\
\hline 1. & $\begin{array}{l}\text { Nagari Ampang } \\
\text { Tulak }\end{array}$ & 25 \\
\hline 2. & $\begin{array}{ll}\text { Nagari } & \text { Batang } \\
\text { Arah } & \end{array}$ & 71 \\
\hline 3. & $\begin{array}{l}\text { Nagari } \quad \text { Batang } \\
\text { Betung }\end{array}$ & 47 \\
\hline 4. & Nagari Bukit Buai & 17 \\
\hline 5. & Nagari Dusun Baru & 25 \\
\hline 6. & Nagari Koto Anau & 24 \\
\hline 7. & $\begin{array}{ll}\text { Nagari } & \text { Pasar } \\
\text { Tapan } & \\
\end{array}$ & 19 \\
\hline 8. & Nagari Riak Danau & 46 \\
\hline 9. & $\begin{array}{ll}\text { Nagari } & \text { Tanjung } \\
\text { Pondok } & \\
\end{array}$ & 34 \\
\hline 10. & Nagari Tapan & 24 \\
\hline \multicolumn{2}{|c|}{ Kec. Basa Ampek Balai } & 332 \\
\hline
\end{tabular}

Sumber: Pendamping PKH Kec. Basa Ampek Balai tahun 2018

Berdasarkan data diatas terlihat bahwa jumlah KPM dikecamatan Basa Ampek Balai 332 hanya 25,61 \% yang mendapatkan bantuan sosial PKH dari jumlah penduduk miskin 1.296 jiwa dengan total jumlah penduduk Kecamatan Basa Ampek Balai 13.793 jiwa. Dan KPM PKH yang terpilih tidak sesuai sasaran Program Keluarga Harapan dari PERMENSOS RI
No 1 Tahun 2018, namun terdaftar pada Basis Data Terpadu Penanggulangan Kemiskinan. Sehingga 74,39 \% keluarga yang memiliki kriteria sebagai penerima Program Keluarga Harapan yang tergolong penduduk miskin belum mendapatkan bantuan sosial $\mathrm{PKH}$ tersebut.

Program ini menjangkau aspek yang paling bawah yaitu mensejahterakan masyarakat melalui kesejahteraan keluarga. program $\mathrm{PKH}$ yang sudah di implementasikan diberbagai daerah di Indonesia, PKH menunjukkan keberhasilannya dalam memberantas kemiskinana yang ada didaerah, akan tetapi dibeberapa daerah program ini belum berhasil diimplementasikan dengan baik dalam memberantas kemiskinan, yang dibuktikan dengan meningkatnya jumlah penduduk miskin didaerah tersebut (Virgoreta, 2015; Kholif, 2014)

Dari berbagai artikel yang telah dibaca diatas peneliti belum menemukan keterkaitan Implementasi Program Keluarga Harapan dengan peraturan Menteri Sosial RI Tahun 2018 Tentang PKH pada artikel lainnya, sehingga Implementasi Program Keluarga Harapan yang berhasil atau tidak tersebut didilihat dari aspek yang seperti apa, sebab dalam Peraturan Mneteri Sosial RI No 1 Tahun 2018 ini mengatur segala aspek baik dari sasaran, komponen, Hak dan Kewajiban serta Proses Pendampingan maupun Mekanisme dari PKH itu sendiri. Sehingga objek penelitian yang akan dilakukan adalah Implementasi Peraturan Menteri Sosial RI No 1 Tahun 2018 Tentang Program Keluarga Harapan studi Masyarakat di kecematan Basa Ampek Balai Tapan yang berusaha mengidentifikasi 
Implementasi Program dengan Peraturan Menteri sosial RI No 1 Tahun 2018 yakni peneliti menemukan masalah nyata yakni Implementasi PERMENSOS RI No 1 Tahun 2018 sudah dilaksanakan namun belum sesuai dengan komponen misalnya penentuan peserta $\mathrm{PKH}$ ini berdasarkan komponen masyarakat miskin yang rentan dalam hal kesehatan (Ibu hamil dan balita umur 0-6 Tahun), pendidikan (SD,SMP,SMA umur 6-21 Tahun yang belum menamatkan pendidikan), Kesejahteraan Sosial (Lanjut Usia umur 60 Tahun dan Disabiitas Berat). Namun penentuan Peserta PKH ini berdasarkan PERMENSOS No 1 Tahun 2018 dan Basis Data Terpadu Penanggulangan Kemiskinan Tahun 2015 sehingga realita dilapangan data tersebut tidak sesuai dengan kondisi masyarakat yang sekarang. Sehingga muncul ketidakadilan dari masyarakat yang tidak menerima PKH mengenai peristiwa tersebut. Permaslahan lain yaitu pemberian akses KIP,KIS dan Rastra namun masyarakat Keluarga Pnerima Manfaat tidak menggunakan dengan maksismal sehingga Implementasi PKH belum dimplementasikan dengan baik.

Kelemahan dan keterbatasan yang ditemui dalam Implementasi Program Keluarga Harapan bahwa penentuan perserta PKH yang berdasarkan penggunaan Basis Data Terpadu Penanggulangan Kemiskinan Tahun 2015 oleh kementrian Sosial RI harus segera dilakukan pembaharuan data, mengingat kondisi masyarakat yang sekarang ini sudah berkembang dari segi kesejahtraannya, dengan demikian baik masyarakat yang menerima PKH sesuai dengan komponen yang tertera dalam
Peraturan Menteri No 1 Tahun 2018 dan masyarakat yang tidak menerima PKH juga tidak komplen terhadap program yang dirasa tidak adil dalam menentukan sasaran.

Tujuan penelitian ini yaitu Untuk mendeskripsikan Imlementasi Peraturan Menteri Sosial RI Nomor 1 Tahun 2018 Tentang Program Keluarga Harapan di Kecamatan Basa Ampek Balai, Kabupaten Pesisir Selatan. Dan Untuk mengidentifikasi berbagai Penilaian masyarakat yang Menerima Bantuan Dana Sosial dan yang tidak menerima Bantuan terhadap Implementasi Peraturan Menteri Sosial RI Nomor 1 Tahun 2018 Tentang Program Keluarga Harapan. Bersarkan tujuan penelitian diatas, maka manfaat penelitian dalam penelitian ini adalah sebagai berikut: Manfaat Teoritis: Hasil penelitian dapat memperluas dan memperkaya serta memperdalam pemahaman mengenai Implementasi Peraturan Menteri Sosial RI Nomor 1 Tahun 2018 Tentang Program Keluarga Harapan, Memberikan sumbangan pemikiran bagi peneliti lain untuk melakukan penelitian baru tentang Peraturan Menteri Sosial RI Nomor 1 Tahun 2018 Tentang Program Keluarga Harapan. Manfaat Praktis : Manfaat Bagi penulis Manfaat bagi Masyarakat dan Manfaat Bagi pemerintah Agar dapat memberikan manfaat pada pemerintah sebagai bahan pertimbangan atau acuan untuk mengawasi Implementasi Peraturan Menteri Sosial RI Nomor 1 Tahun 2018 Tentang Program Keluarga Harapan dibeberapa daerah.

\section{METODE PENELITIAN}

$\begin{array}{lcr}\text { Jenis } & \text { penelitian ini adalah } \\ \text { pendekatan } & \text { kualitatif } & \text { dengan } \\ \text { menggunakan } & \text { metode } & \text { penelilitian }\end{array}$


studi Kasus. Lokasi penelitian ini dilakukan di Kecamatan Basa Ampek Balai, Kabupaten Pesisir Selatan disebabkan dari 15 Kecamatan yang ada di Kabupaten Pesisir selatan, Kecamatan Basa Ampek Balai yang megalami peningkatan peserta $\mathrm{PKH}$ yang signifikan dari tahun ke tahun dalam artian tujuan program $\mathrm{PKH}$ yaitu pengentasan kemiskinan yang dibuktikan dengan semakin menurunnya peserta $\mathrm{PKH}$ dan pada kecamatan Basa Ampek Balai terindentifikasi belum adanya ketercapaian tujuan program, Teknik Pengumpulan data dengan jenis data primer dala penelitian ini diperoleh melalui Wawancara dan Observasi dengan informan penelitian yang menaungi Program Keluarga Harapan (PKH).dengan jumlah informan yaitu 26 orang, terdiri dari 2 orang pihak Dinas sosial, 1 camat Kecamatan Basa Ampek Balai, 10 orang Wali Nagari, dan 2 Tokoh Masyarakat dan 1 pendamping PKH, 7 Masyarakat Keluarga Penerima Manfaat PKH, 3 Orang Masyarakat tidak menerima bantuan PKH. Sedangkan data sekunder diperoleh dari dokumendokumen peserta PKH pada pendamping Kecamatan Basa Ampek Balai dan data PKH se kecamatan dari Dinas Sosial Kabupaten Pesisir Selatan. Selanjutnya teknik analisis data yang digunakan adalah data reduction (reduksi data), data display (penyajian data), dan conclusion drawing/verification (penarikan kesimpulan).

\section{HASIL DAN PEMBAHASAN}

1. Implementasi Program Keluarga Harapan Di Kecamatan Basa Ampek Balai Berdasarkan Peraturan Menterin RI No 1 Tahun
2018 Tentang Program Keluarga Harapan

a. Analisis Kebijakan Program Keluarga Harapan dari Pusat ke Darah dan Kabupaten

Program Keluarga Harapan merupakan program perlindungan sosial yang bersifat memberikan bantuan pada RTSM dalam bidang pendidikan dan kesehatan sebagai bentuk perlindungan sosial oleh pemerintah kepada masyarakat. kebijakan PKH merupakan kebijakan dengan menggunakan Model Implementasi Top-Down bahwa kebijakan model Top-Down merupakan kebijakan dari pemerintah pusat yang dilimpahkan pada daerah. Seperti yang dikemukan oleh Sabatier (1983) dan Ratmono (2008) implementasi kebijakan dengan pendekatan Top-Down merupakan proses pelaksanaan keputusan kebijakan mendasar yang dilakukan secara desentralisasi dan dimulai dari aktor pusat serta keputusannya yang dibuat (dalam Mulyadi, Deddy. (2015). Implementasi Peraturan Menteri Sosial RI No 1 Tahun 2018 tentang Program Keluarga Harapan pada kecamatan Basa Ampek Balai belum diimplementasi dengan baik, hal ini dibuktikan dengan semakin banyak peserta PKH dari tahun ke tahun mulai dari tahun 2016294 Keluarga Penerima Manfaat , kemudian terjadi penghapusan KPM sebanyak 3 Keluarga sehingga jumlah KPM PKH pada tahun 2017 menjadi 291 KPM dan tahun 2018 terjadi Penambahan KPM sebanyak 41 sehingga menjadi 332 KPM. Berdasarkan data diatas jika ditinjau dari tujuan Program Kelaurga Harapan yaitu untuk mengurangi angka kemiskinan yang dibuktikan dengan menurunnya Keluarga 
Penerima Manfaat PKH berkurang bukan malah meningkat.

Implementasinya $\mathrm{PKH}$ ini belum berjalan optimal di Kecamatan Basa Ampek Balai adalah dari analisis Kebijakan yang berdasarkan pendekatan Top-Down yakni kebijakan yang bersifat desentralisasi yakni pelimpahan kebijakan dari pusat ke daerah, dalam artian kebijakan Program Keluarga Harapan merupakan kebijakan yang diputuskan oleh pusat dari Kementrian Sosial RI yang berpedoman dari Basis Data Terpadu Penanggulangan Kemiskinan (BDT) tahun 2015 selain itu ditunjang oleh Peraturan Menteri Sosial RI No 1 Tahun 2018 mengenai penetapan sasaran program, meskipun demikian dari BDT Tahun 2015 dalam penetapan sasaran, namun data BDT tersebut tidak sesuai dengan realitas kehidupan masyarakat yang jauh lebih maju. Pernyataan data tersebut peneliti dapatkan melalui wawancara, observasi dan dokumentasi bahwa kebijakan tersebut membuat masyarakat yang menerima PKH yang sebelumnya terdaftar pada BDT tahun 2015 masih dengan status miskin namun seiring perubahan zaman kehidupan berubah sehingga banyak Peserta PKH yang sudah sejahtera mendapatkan bantuan. Oleh sebab itulah masyarakat yang tidak menerima PKH merasa Program tidak objektif dalam penetapan peserta $\mathrm{PKH}$ sehingga menimbulkan kecemburuan sosial dan melampiaskan kemarahan pada Pemerintah Nagari yang sama sekali tidak terlibat dengan Program Keluarga Harapan dan untuk pihak $\mathrm{PKH}$ baik Koordinator kabupaten/kota, Dinas Sosial, Supervisor dan Pendamping PKH di
Kecamatan tidak bisa melakukan apaapa dikarenakan penetapan Peserta PKH langsung dari Menteri Sosial RI, sehingga permasalahan Kebijakan dari Pusat, Daerah dan Nagari ini menyebabkan Implementasi PKH tidak optimal dilakukan.

\section{b. Dampak Implemntasi Program Keluarga Harapan}

Implementasi

Program

Keluarga Harapan Keberhasilan suatu kebijakan tergantung pada Implementasi dan perspektif hasil, artinya apabila program pemerintah membawa dampak sesuai dengan ketentuan. Sehingga dapat dikatakan suatu program bisa saja berhasil apabila dilihat dari proses, dan bisa saja gagal jika ditinjau dari dampak yang dihasilkan. Hal ini sesuai dengan yang dikatakan oleh Sebatier (1998) bahwa fator yang memepengaruhi kesuksesan dan kegagalan Implementasi dapat dilihat salah satunya dari Komitmen dan Keahlian para pelaksana kebijakan, dukungan para Stekeholder, tujuan dan sasaran yang jelas. Implementasi Program Keluarga Harapan dilihat dari Dampak di bidang kesehatan, pendidikan, kesejahteraan sosial dalam bidang kesehatan sudah dirasakan oleh masyarakat khususnya ibu hamil dan balita yang rutin melakukan cek kesehatan 4 kali dalam 2 bulan sebelumnya 1 kali 3 bulan namun untuk hak KPM PKH mendapatkan KIS, rata-rata akses KIS sudah didapatkan KPM PKH secara keseluruhan akan tetapi KPM PKH belum secara menyeluruh menunaikan kewajibannya untuk memeriksakan kesehatan pada puskesmas dan posyandu terdekat, bedasarkan pernyataan informan peneitian terkadang keluarga mereka jarang 
menggunakan akses KIS disebabkan jarang sakit parah, dan adapun informan peneloitian yang menggunakan KIS di puskesmas akan tetapi data mereka tidak ditemukan dipuskesmas, sehingga perubahan dalam bidang kesehatan belum optimal dirasakan dan dilaksankan oleh KPM PKH. Selanjutnya bidang pendidikan ditemukan bahwa belum teriimplementasi dengan baik, hal ini masih banyak KPM PKH tidak mendapatkan KIP secara merata, sebagian anak KPM mendapatkan KIP tetapi sudah berkeluarga. Dan KPM PKH yang lain juga menjelaskan bahwa anaknya pendapatkan KIP. Namun tidak pernah berlaku disekolah dalam mengurus beasiswa. Meskipun pendamping dan Pihak Dinas Sosial menyatakan itu keputusan pusat dan kemampuaan anngaran Pemerintah. Sehingga dari pernyataan tersebut dampak implementasi PKH dalam bidang pendidikan belum optimal di implementasikan. Dampak Implementasi Keluarga Penerima Manfaat (KPM/PKH) mengalami perubahan dalam perekonomian.

\section{c. Hambatan Implementasasi Program Keluarga Harapan di Kecamatan Basa Ampek Balai}

Dalam Implementasi kebijakan wajar terjadi hambatan hal ini sesuai dengan yang diungkapkan oleh Wahyu, Nurharjhamo bakwa Implementasi merupakan studi mengetahui proses Implementasi yang bertujuan untuk mengetahui hambatan dan masalah dalam proses implementasi yang dilaksanakan secara terencana berdasarkan standar yang telah ditentukan. Faktor lain yang menyababkan Implementasi
Program belum optimal adalah Faktor penghambat yang dirasakan dari ketidak terlibatan pemerintah nagari dalam penetapan sasaran, keterbatasan akses jaringan dan transportasi dari Pendamping dan masyarakat yang non KPM menginginkan penambahan kuota peserta PKH ke Dinas Sosial. Akibatnya pemerintah nagari sering mengalami berbagai tudingan masyarakat mengenai PKH yang tidak tepat sasaran sehingga permasalahan PKH seperti yang tidak dapat KIS, KIP dan Rastra banyak masyarakat yang menuntut ke pemerintah nagari bukan pada pihak $\mathrm{PKH}$, namun secara umum pemerintah nagari ikut serta dalam membantu seperti pembukaan atau sambutan pada pencairan dana tetapi urusaan lain dari pada itu pemerintah nagari tidak ada kaitannya. Hambatan dari pendamping $\mathrm{PKH}$ yaitu peserta $\mathrm{PKH}$ sendiri seperti pencairan dana PKH yang diwakilkan kepada kerabat atau anak dari peserta PKH yang sejatinya pencairan dana harus diambil langsung oleh peserta $\mathrm{PKH}$ kemudian faktor selanjutnya terletak pada masalah jaringan internet yang mana pendamping $\mathrm{PKH}$ menggunakan suatu system untuk melakukan pemuktahiran data ke pusat, selanjutnya adalah kecemburuan sosial dari masyarakat yang tidak menerima $\mathrm{PKH}$ melaui berbagai kritikan, hinaan untuk menunjukkkan rasa kecewanya. Dari temuan dilapangan terlihat bahwa sosialisasi PKH kepada masyarakat belum optimal. Hambatan Dinas Sosial bahwa pemerintah pusat yang memiliki wewenang terhadap masalah KPM PKH banyak yang sejahtera mendapatkan PKH, Penetapan target PKH itu berdasarkan BDT dan 
PERMENSOS RI No 1 Tahun 2018 Kementerian sosial RI, artinya Implementasi PKH menggunakan model Implementasi Top-down sehingga Basis data terpadu penanggulangan kemiskinan yang dipakai masih BDT lama, sedangkan pihak Dinas Sosial mengatakan bahwa sedang melakukan varivali data yang akan rampung secepatnya.

\section{d. Faktor Pendukung Implementasi Program Keluarga Harapan}

Faktor pendukung Implementasi Program Keluarga Harapan yang dirasakan pendamping Program Keluarga Harapan yakni Keuletan dan kerja keras Pendamping $\mathrm{PKH}$ walaupun terbatas akses jangkauan transportasi ke 10 kenagarian. Hal ini dibuktikan dengan tingkat kehadiran peserta PKH atau yang dikenal dengan Keluarga Penerima Manfaat dalam sosialisasi maupun pertemuan kelompok cukup baik yang diakan setiap bulannya, selanjutnya Kemudahan komunikasi dan berkoordinasi ke Dinas Sosial dalam permasalahan $\mathrm{PKH}$, hal ini dilihat dari keterlibatan dan Koordinasi pejabat PKH yang dikabupaten setiap tahun melakukan penyuluhan di Kecamatan Basa Ampek Balai kepada peserta PKH baik dalam memberikan Informasi kepada KPM PKH maupun menyelesaikan masalah yang dihadapi oleh peserta Program Keluarga Harapan.

2. Penilaian dan Pemahaman masyarakat yang menerima $\mathrm{PKH}$ dan Mayarakat yang tidak menerima PKH

\section{a. Penilaian masyarakat yang} menerima PKH

Program bantuan untuk sekolah dan pendidikan saja, namun untuk KIS peserta $\mathrm{PKH}$ pada umumnya masih mendapatkan, akan tetapi Peserta PKH jarang menggunakan kartu KIS untuk berobat hanya digunakan ketika melahirkan dengan alasan anggota keluarga yang lain jarang sakit, sedangkan KIP jarang didapatkan secara merata bagi peserta PKH selama penelitian paling banyak peserta $\mathrm{PKH}$ yang anaknya masih bersekolah hanya mendapatkan 2 (dua) KIP saja, dan itupun masyarakat PKH tidak ada yang mengetahui kegunaannya, kemudian penilaian dan pemahaman peserta PKH dalam penggunaan Dana PKH hampir sebagian informan digunakan untuk kebutuhan pokok, dan sebagian lagi digunakan untuk keperluan pendidikan, hanya sebagian kecil masyarakat penerima $\mathrm{PKH}$ yang mengerti kegunaan dana sosial PKH ini, sedangkan pihak Dinas sosial hanya menyampaikan bahwa masalah KIS dan KIP yang belum merata itu tergantung kesanggupan Pemerintah Daerah dan Pusat dalam hal tersebut.

\section{b. Penilaian Dari Masyarakat Yang Tidak Menerima Bantuan PKH.}

Kebanyakan

masyarakat mengeluh dengan system pendataan penerima PKH yang menggunakan BDT (Basis Data Terpadu) penanggulangan Kemiskinan yang lama diterapkan sebagai patokan dalam menetukan penerima $\mathrm{PKH}$ tanpa melihat kenyataan dilapangan, akibat kekecewaan ini dikarenakan tidak ada penyuluhan dan peinformasian kepada masyarakat secara umum tentang proses pendataan dan komponen calon penerima $\mathrm{PKH}$ itu sendiri, namun pernyataan ini pendamping $\mathrm{PKH}$ dan Kasi Bantuan dan Jaminan sosial menyatakan bahwa untuk penyaluran memang dilakukan kepada peserta 
PKH saja, karena masyarakat lain jika dijelaskan juga mereka tidak paham mengenai PKH sebab tidak menerima PKH. Sehingga hal ini lah menyebabkan penilaian dan pemahan masyarakat berkutat pada permasahan itu saja tanpa ada jalan keluar pengimpormasian kepada masyarakat secara umum.

\section{KESIMPULAN}

Program Keluarga Harapan merupakan suatu program yang dikeluarkan oleh pemerintah yang diatur dalam Peraturan Menteri Sosial RI No 1 Tahun 2018 yang memberikan bantuan kepada masyarakat yang rentan dalam segi Kesehatan dan Pendidikan serta Kesejahteraan sosial, melalui data Basis Data Terpadu (BDT) untuk menanggulangi fakir miskin yang langsung diutus oleh pusat ke berbagai daerah di Indonesia. Implementasi Program Keluarga Harapan sudah diimlmentasikan di Kecamatan Basa Ampek Balai Namun dalam segi implementasi program berdasarkan PEREMENSOS No 1 Tahun 2018 belum menunjukkan hasil yang memuaskan dalam menangulangi kemiskinan khususnya di Kecamatan Basa Ampek Balai, hal ini dibuktikan dengan semakin meningkatnya peserta PKH dari tahun ke tahun dari 2016 hanya sekitar 294 kemudian terjadi penghapusan peserta PKH sebanyak 3 Keluarga Penerima Manfaat yang sudah sejahtera, hingga awal 2018 tercatat yang menerima PKH sebanyak $332 \mathrm{KPM}$. Hal ini di perburuk dengan peserta PKH yang masih banyak tidak mendapatkan haknya dalam KIP da rastra didukung dengan kesadaran masyarakat yang kurang dalam penunjang terlaksanya Komponen serta kewajiban $\mathrm{PKH}$
Volume 1 No. 22018

dalam Kesehatan dan Pendidikan.Sedangkan untuk masyarakat penerima $\mathrm{PKH}$ banyak ang tidak memahami PKH secara menyeluruh mengenai sasaran dan komponen penerima, sehingga muncul berbagai spekulasi dan kecemburuan sosial di kalangan masyarakat itu sendiri.

\section{DAFTAR PUSTAKA}

Kholif, K. I. (2014). Implementasi Program Keluarga Harapan (PKH) dalam Menanggulangi Kemiskinan di Kecamatan Dawarblandong Kabupaten Mojokerto. Jurnal Administrasi Publik, 2(4), 709-714.

Monalisa, M., Andriyus, A., \& Uyun, R. (2018). Implementasi Peraturan Menteri Dalam Negeri Nomor 56 Tahun 2015 Tentang Kode Dan Data Wilayah Administrasi Pemerintahan (Studi Di Kabupaten Kampar Dan Kabupaten Rokan Hulu). WEDANA: Jurnal Kajian Pemerintahan, Politik dan Birokrasi, 4(2), 509-522.

Mulyadi, Deddy. (2015). Study Kebijakan Public Dan Pelayanan Publik. Bandung: Alfabeta.

Peraturan Mentri Sosial No 1 Tahun 2018tentang Program Keluarga Harapan

Purwanto. (2012). Implementasi Kebijakan Publik. Yogyakarta: Grava Media.

Sabatier, P. A. (1986). Top-down and bottom-up approaches to implementation research: a critical analysis and suggested synthesis. Journal of public policy, 6(1), 21-48. 
132 | Implementasi Program..

Utomo, D. (2014). Pelaksanaan

Program Keluarga Harapan

Dalam Meningkatkan Kualitas

Hidup Rumah Tangga Miskin

(Studi Pada Unit Pelaksana

Program Keluarga Harapan

Kecamatan Purwoasri

Kabupaten Kediri). Jurnal

Administrasi Publik, 2(1), 29-34.

Virgoreta, D. A. (2015). Implementasi

Program Keluarga Harapan

(PKH) Dalam Upaya

Meningkatkan Kesejahteraan Masyarakat (Studi pada Desa

Beji Kecamatan Jenu,

Kabupaten Tuban). Jurnal

Administrasi Publik, 3(1), 1-6. 